\title{
Presence of Restricted Killer Immunoglobulin-Like Receptor Repertoire and Monoclonal T-Cell Receptor $\gamma$ Rearrangement as Evidence of Mixed NK/T-Cell Differentiation in a Subset of Sinonasal Lymphomas
}

\author{
Chung-Wu Lin, Jia-Ying Yang, Yi-Chun Chuang, Yu-Hua Chen, Maher Albitar, and \\ Su-Ming Hsu
}

Department of Pathology (C-WL, J-YY, Y-CC, Y-HC, S-MH), National Taiwan University Hospital, National Taiwan University College of Medicine, Taipei, Taiwan; and Department of Hematopathology (MA), MD Anderson Cancer Center, University of Texas, Houston, Texas

\begin{abstract}
SUMMARY: Most sinonasal lymphomas have a restricted killer immunoglobulin-like receptor (KIR) repertoire without a monoclonal T-cell receptor- $\gamma(\mathrm{TCR}-\gamma)$ rearrangement, implying an NK lineage. However, the lineage assignment of sinonasal lymphoma with a monoclonal TCR- $\gamma$ rearrangement is unclear because of its mixed NK/T phenotype. The possibility of a mixed $\mathrm{NK} / \mathrm{T}$ lineage arises with the discovery of $\mathrm{T}$ cells with NK features, such as $\mathrm{KIR}^{+} \mathrm{T}$ cells or $\mathrm{V} \alpha 24^{+} \mathrm{NKT}$ cells. The former might transform into a T-cell lymphoma with both a monoclonal TCR- $\gamma$ rearrangement and a restricted KIR repertoire; the latter might give rise to a T-cell lymphoma with a monoclonal $\mathrm{V} \alpha 24$ rearrangement and possibly a restricted KIR repertoire. To identify such mixed-lineage lymphomas, we undertook a survey of 15 consecutive sinonasal lymphomas and found six with both a restricted $\mathrm{KIR}$ repertoire and a monoclonal TCR- $\gamma$ rearrangement, consistent with $\mathrm{KIR}^{+} \mathrm{T}$-cell lymphomas. Among these six cases, four female $\mathrm{CD}^{-} 6^{-} / \mathrm{CD}_{4} 4^{-} / \mathrm{CD}^{-} / \mathrm{CD} 45 \mathrm{RO}^{+} / \mathrm{CD} 45 \mathrm{RA}^{-}$cases constituted a distinct group with a better prognosis than the rest of the male cases of sinonasal lymphomas. None of the six cases had a monoclonal $\mathrm{V} \alpha 24$ repertoire, thus excluding a derivation from NKT cells. The predominance of $\mathrm{KIR}^{+} \mathrm{T}$ cells that normally function in chronic viral infections over $\mathrm{V} \alpha 24^{+}$NKT cells that typically recognize glycolipid antigens is consistent with the known association of Epstein-Barr virus infection with sinonasal lymphoma. The demonstration of mixed lineage in a mature lymphoid neoplasm is unusual and echoes the World Health Organization classification that placed NK-cell and T-cell lymphomas in a mixed group. (Lab Invest 2003, 83:55-64).
\end{abstract}

$I$ $\mathrm{n}$ the World Health Organization (WHO) classification (Jaffe et al, 2001), NK-cell and T-cell lymphomas are placed in a mixed group, in part because some NK/T lymphomas, such as sinonasal lymphoma (SNL), have an ambiguous phenotype, making assignment to the NK- or T-lineage difficult. SNL is simply designated as extranodal NK/T-cell lymphoma, nasal type, without further specification of its lineage. This designation also implies possibly the existence of a lymphoma of truly mixed NK/T lineage, which, however, has not yet been demonstrated.

SNLs express some T-cell related antigens, such as $\mathrm{CD} 2$, cytoplasmic CD3, and CD7, but not surface

DOI: 10.1097/01.LAB.0000047491.62596.A3

Received August 13, 2002.

The research funding was provided through Grants NTUH-S901000-27 and NTUH-S91-A12 to C-WL, EDU-90-B-FA01-1-4, NSC90-2314-B-002-151, and NHRI-EX91-8704SL to S-MH, from National Taiwan University Hospital (NTUH), the National Science Council (NSC), and the National Health Research Institute (NHRI), Taiwan.

Address reprint requests to: Dr. Su-Ming Hsu, Department of Pathology, National Taiwan University College of Medicine, Jen-Ai Road, Taipei, Taiwan 10016. E-mail: smbsu@ha.mc.ntu.edu.tw
CD3, CD4, CD5, or CD8 (Suzumiya et al, 1994). Despite this ambiguous phenotype, most SNLs are considered NK-cell lymphomas because of the absence of a monoclonal T-cell receptor (TCR) rearrangement and expression of an NK-cell marker, CD56.

Recently, NK cells were found to express clonotypical killer immunoglobulin-like receptors (KIRs) (Long and Rajagopalan, 2000; Moretta et al, 1996). KIRs share a consensus sequence of three Ig-like domains, and can be classified as KIR2DL4, KIR2D, or KIR3D, with two or three domains due to alternative splicing. These receptors were randomly distributed over three alternative splicing groups in a polyclonal NK-cell population, but were restricted to one or two groups in SNLs. Thus, a restricted KIR repertoire $\left(r-\mathrm{KIR}^{+}\right)$without a monoclonal TCR rearrangement $\left(r-\mathrm{TCR}^{-}\right)$in the majority (approximately 60\%) of SNLs further confirms their origin from the true NK lineage (Lin et al, 2001).

However, the nature of some SNLs with a monoclonal TCR rearrangement $\left(\mathrm{r}-\mathrm{TCR}^{+}\right)$remains to be clarified. These lymphomas are usually $\mathrm{CD}^{-} 6^{-}$and considered to be of T-cell nature (Chiang et al, 1997; Nagata et al, 2001), even though the status of KIR expression of these lymphomas is unknown. The 
simultaneous expression of KIRs and TCR rearrangement is unusual, but would indicate an origin from $\mathrm{KIR}^{+} \mathrm{T}$ cells (Bertrand and Karlsson, 2000; McMahon and Raulet, 2001; Mingari et al, 1996; Ugolini et al, 2001). $\mathrm{KIR}^{+}$T cells are sometimes confused with NKT cells (Godfrey et al, 2000), which are T cells characterized by an invariant TCR- $\alpha$ chain, $\mathrm{V} \alpha 24 \mathrm{~J} \alpha \mathrm{q}$, combined with the expression of certain NK-cell receptors. Some human $\mathrm{V} \alpha 24^{+}$NKT cells, especially those from the liver (hepatic NKT), are $\mathrm{KIR}^{+}$(Norris et al, 1999; Raulet et al, 2001).

In this study, we attempted to clarify the nature of $\mathrm{r}$-TCR ${ }^{+}$SNLs in relation to the expression of KIRs and $\mathrm{V} \alpha 24$. We show the presence of restricted KIR repertoires and absence of $\mathrm{V} \alpha 24$ (ie, $r-\mathrm{KIR}^{+} \mathrm{N} \alpha 24^{-}$) in $r$-TCR ${ }^{+}$SNLs that are typically associated with Epstein-Barr virus (EBV) infection. It is interesting to note that $\mathrm{KIR}^{+} \mathrm{T}$ cells generally function to fight viral infection, whereas the NKT cells typically recognize glycolipid antigens.

\section{Results}

\section{Restricted KIR Repertoire Plus Monoclonal TCR- $\gamma$ Rearrangement Identifies a r-KIR ${ }^{+} / r-T C R^{+}$Lymphoma, Consistent with an Origin from KIR+ T Cells}

In our classification scheme, the presence of a monoclonal TCR $-\gamma$ rearrangement without a restricted KIR repertoire $\left(r-\mathrm{KIR}^{-} / r-\mathrm{TCR}^{+}\right)$indicates a $\mathrm{T}$ lineage, whereas the presence of a restricted $\mathrm{KIR}$ repertoire without a monoclonal TCR rearrangement $\left(r-\mathrm{KIR}^{+} / \mathrm{r}-\right.$ $\mathrm{TCR}^{-}$) indicates an NK lineage. The presence of a restricted KIR repertoire plus a monoclonal TCR rearrangement $\left(r-\mathrm{KIR}^{+} / \mathrm{r}-\mathrm{TCR}^{+}\right)$indicates a $\mathrm{KIR}^{+} \mathrm{T}$-cell lymphoma (Table 1$)$.

We used a reverse transcription-polymerase chain reaction (RT-PCR) approach for analysis of KIRs (Lin et al, 2001). These receptors have a consensus sequence composed of three Ig-like domains, and can be divided into three groups due to alternative splicing. Because these clonotypical receptors are randomly distributed, a reactive condition involving polyclonal NK cells would have an unrestricted KIR repertoire of all three groups. Conversely, a KIR repertoire restricted to one or two of the three groups would signify an NK-cell lymphoma (Lin et al, 2001). A typical result of the KIR repertoire analysis is shown in Figure 1. We have also used a PCR-based approach to analyze the V-J junctional diversity (Lin et al, 2002). The variable regions of the TCR- $\gamma$ locus can be put into 4 groups: $V \gamma l, V \gamma l l, V \gamma l l l$, and $V \gamma I V$. Figure 2 illustrates a representative T-cell Iymphoma, which has a monoclonal pattern of $\mathrm{V} \gamma \mathrm{III}$ and a polyclonal pattern of $\mathrm{V} \gamma \mathrm{I}, \mathrm{V} \gamma \mathrm{Il}$, and $\mathrm{V} \gamma \mathrm{IV}$.

As shown in Table 2, six of 15 consecutive SNLs had a monoclonal TCR- $\gamma$ rearrangement plus a restricted KIR repertoire, consistent with a $\mathrm{KIR}^{+} \mathrm{T}$ lineage $\left(r-\mathrm{KIR}^{+} / \mathrm{r}-\mathrm{TCR}^{+}\right)$. Nine cases had a detectable restricted KIR repertoire without a monoclonal TCR rearrangement, consistent with a true NK lineage $\left(\mathrm{r}-\mathrm{KIR}^{+} / \mathrm{r}-\mathrm{TCR}^{-}\right)$. Among the 12 peripheral T-cell lymphomas (PTLs) with a monoclonal TCR- $\gamma$ rearrangement, we found only one case with a KIR repertoire, consistent with a $\mathrm{KIR}^{+} \mathrm{T}$ lineage $\left(\mathrm{r}-\mathrm{KIR}^{+} / \mathrm{r}-\mathrm{TCR}^{+}\right)$. This is Case 4 diagnosed as PTL, unspecified, in the PTL group of Table 2.

\section{Absence of a Monoclonal Vo24 Repertoire by Reverse Transcriptase-Polymerase Chain Reaction Excludes an NKT-Cell Lymphoma}

$\mathrm{KIR}^{+} \mathrm{T}$ cells $\left(\mathrm{r}-\mathrm{KIR}^{+} / \mathrm{r}-\mathrm{TCR}^{+}\right)$might be confused with NKT cells $\left(\mathrm{V} \alpha 24^{+} / \mathrm{r}-\mathrm{TCR}^{+}\right)$, some of which are also $\mathrm{KIR}^{+}$(Godfrey et al, 2000). Most T cells use a TCR to recognize peptide antigen in complex with a major histocompatibility complex molecule, but NKT cells are specialized T cells characterized by a specific TCR with an invariant $\alpha$ chain, $\mathrm{V} \alpha 24 \mathrm{~J} \alpha \mathrm{q}$ (Porcelli et al, 1993; Prussin and Foster, 1997).

Using an RT-PCR approach to characterize the $\mathrm{V} \alpha 24$ repertoire, we found that only one PTL case, Case 8 of the PTL group in Table 2, had a monoclonal $\mathrm{V} \alpha 24$ repertoire, suggesting that this lymphoma might be derived from NKT cells. All SNLs tested had either a polyclonal $\mathrm{V} \alpha 24$ repertoire, suggesting the presence of reactive $\mathrm{T}$ cells, or no repertoire at all, suggesting the absence of NKT cells (Fig. 3 and Table 2).

\section{Correlation with Immunohistochemistry}

To confirm and clarify the nature of these $\mathrm{r}-\mathrm{KIR}^{+}$/ $\mathrm{r}$-TCR ${ }^{+}$SNLs, we determined the expression pattern of CD3, CD8, CD44, CDK6 (cyclin dependent kinase 6), CD45RA, CD45RO, and CD56 on SNLs and PTLs (Fig. 4). All of the SNLs were $\mathrm{CD}^{+}$by immunohistochemistry and EBV encoded RNA $\left(\mathrm{EBER}^{+}\right)$by in situ hybridization. Four female patients with $\mathrm{r}-\mathrm{KIR}^{+} / \mathrm{r}-\mathrm{TCR}^{+}$ SNLs were $\mathrm{CD}^{-} 6^{-}$, but the two male patients were $\mathrm{CD}^{+}{ }^{+}$. Most $\mathrm{r}-\mathrm{KIR}^{+} / \mathrm{r}-\mathrm{TCR}^{-} \mathrm{SNLs}$ were $\mathrm{CD}^{+} 6^{+}$(7 of 9), and all PTLs were $\mathrm{CD}^{-} 6^{-}$(12 of 12).

Table 1. Criteria for Lineage Assignment Based on Antigen Receptor Patterns

\begin{tabular}{lcclc}
\hline \multicolumn{1}{c}{ Lineage } & TCR & V $\alpha 24 J \alpha q$ & \multicolumn{1}{c}{ KIR } & TdT \\
\hline T-cell & $r$ & $g$ & absent & - \\
NKT cell & $r$ & $r$ & restricted or absent & - \\
$\mathrm{KIR}^{+}$-T cell & $\mathrm{r}$ & $\mathrm{g}$ & restricted & - \\
NK cell & $\mathrm{g}$ & $\mathrm{g}$ & restricted & - \\
bipotent T/NK precursor & $\mathrm{g}$ & $\mathrm{g}$ & absent & + \\
\hline
\end{tabular}

TCR, T-cell receptor rearrangement; $\mathrm{V} \alpha 24 \mathrm{~J} \alpha \mathrm{q}$, recombination between TCRV $\alpha 24$ and J $\alpha \mathrm{q}$; KIR, killer immunoglobulin-like receptor; TdT, terminal deoxynucleotidyl transferase; $r$, rearranged; $g$, germline. 
A

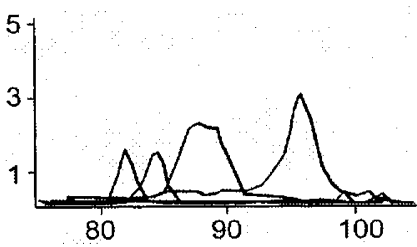

B

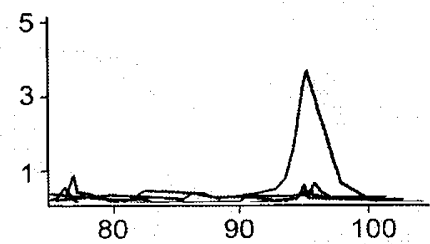

$\mathrm{C}$

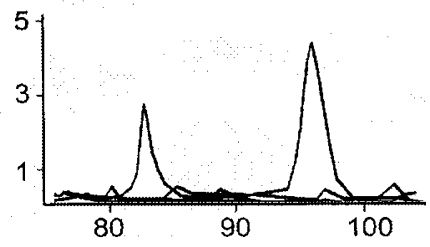

Figure 1.

Killer immunoglobulin-like receptor (KIR) repertoires by reverse transcription-polymerase chain reaction (RT-PCR) are shown for an endometrial biopsy with an unrestricted KIR repertoire (A), a B-cell lymphoma with no detectable KIR repertoire (B), and an NK-cell lymphoma with a restricted KIR repertoire (C). The PCR products were separated by high-resolution electrophoresis (GeneScan). The $x$-axis represents the nucleotide sizes of the PCR products, the $y$-axis is the relative quantity $\left(\times 10^{3}\right)$ of the peaks. The expected sizes of the PCR products for KIR 2DL4, KIR 2D, and KIR 3D are 83, 85, and 90 nucleotides, respectively. The peak of size 96 represents $\beta$-actin, which serves as an internal positive control.

A

B
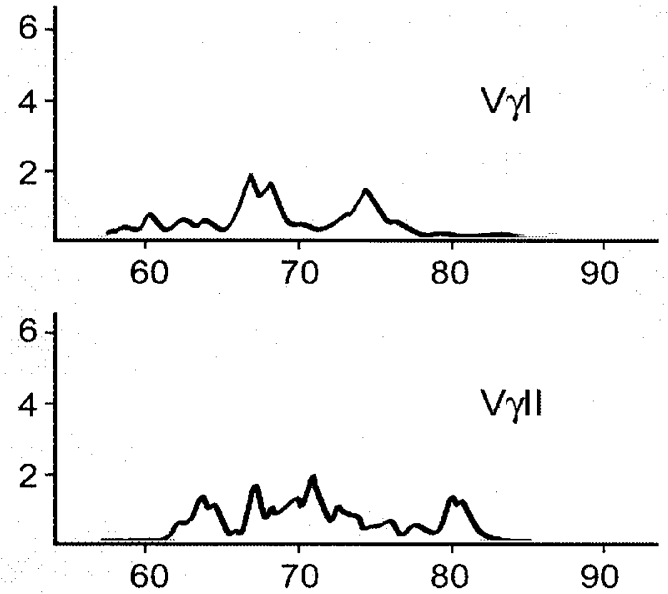

C
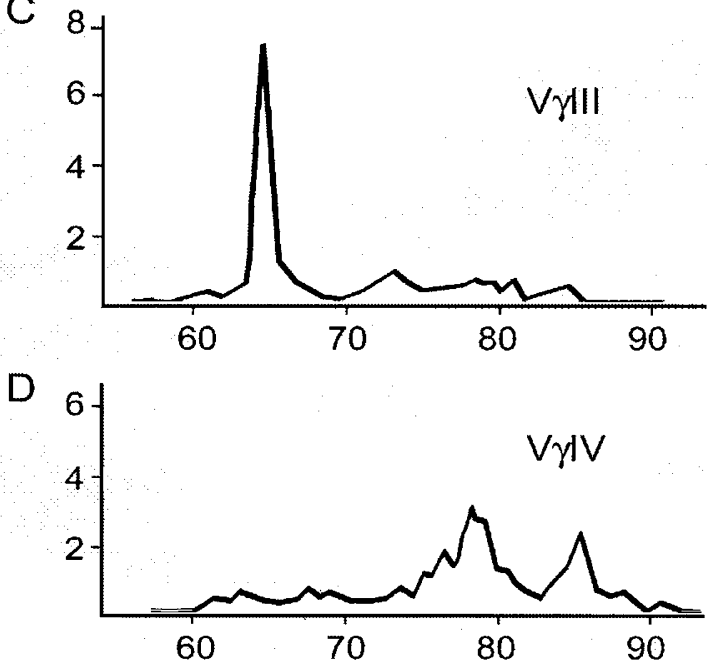

Figure 2.

T-cell receptor- $\gamma$ (TCR- $\gamma$ ) gene rearrangement of a T-cell lymphoma analyzed by four separate nested PCRs. The PCR products were separated by highresolution electrophoresis (GeneScan). The $x$-axis represents the nucleotide sizes of the PCR products, the $y$-axis is the relative quantity $\left(\times 10^{3}\right)$ of the peaks. This particular lymphoma has a monoclonal peak involving $V \gamma / I I-J$ recombination (C), and polyclonal rearrangements of weaker intensities involving $V_{\gamma} \mid-J, V \gamma l l-J$, and $V_{\gamma} I V-J$ rearrangements caused by infiltrating reactive $T$ lymphocytes $(A, B$, and $D)$.

Five of the six $\mathrm{r}-\mathrm{KIR}^{+} / \mathrm{r}-\mathrm{TCR}^{+} \mathrm{SNLs}$ and five of the nine $r-\mathrm{KIR}^{+} / \mathrm{r}-\mathrm{TCR}^{-} \mathrm{SNLs}$ were CD $44^{-}$, but only two of the 12 PTLs were CD44 ${ }^{-}$. Four of the six $\mathrm{r}-\mathrm{KIR}^{+}$/ $\mathrm{r}-\mathrm{TCR}^{+}$SNLs and seven of the nine $\mathrm{r}-\mathrm{KIR}^{+} / \mathrm{r}-\mathrm{TCR}^{-}$ SNLs were $\mathrm{CDK}^{+}$, but only four of the 12 PTLs were $\mathrm{CDK6}^{+}$. This is consistent with our previous report that frequent loss of CD44 and strong expression of CDK6 distinguishes SNLs from PTLs (Lien et al, 2000). The CD44 and CDK6 status of $r-\mathrm{KIR}^{+} / \mathrm{r}-$ $\mathrm{TCR}^{+}$SNLs was more like $\mathrm{r}-\mathrm{KIR}^{+} / \mathrm{r}-\mathrm{TCR}^{-}$SNLs rather than PTLs.

To assess the functional status of $\mathrm{r}-\mathrm{KIR}^{+} / \mathrm{r}-\mathrm{TCR}^{+}$ SNLs further, we compared the expression patterns of the two CD45 isoforms, CD45RO and CD45RA, in SNLs and PTLs. Within the T lineage, CD45RA is a marker for naïve $T$ cells and CD45RO is a marker for memory $T$ cells. Within the NK lineage, NK cells differentially express CD45RA and CD45RO, depending on the activation status (Warren and Skipsey, 1991). We found that, regardless of lineage assignment, SNLs as well as PTLs express predominantly the CD45RO isoform. The expression pattern of CD45RA versus CD45RO does not distinguish between these diseases. We have also determined the expression of CD8. In consistence with previous reports (Kanavaros et al, 1993), we found most $\mathrm{r}-\mathrm{KIR}^{+} /$ $\mathrm{r}-\mathrm{TCR}^{+}$SNLs, $r-\mathrm{KIR}^{+} / \mathrm{r}-\mathrm{TCR}^{-} \mathrm{SNLs}$, and PTLs were $\mathrm{CD}^{-}$.

Taken together, we found that, among the 6 $\mathrm{r}-\mathrm{KIR}^{+} / \mathrm{r}-\mathrm{TCR}^{+} \mathrm{SNLs}$, the most common phenotype was $\mathrm{CD}^{-} 6^{-} / \mathrm{CD}_{4} 4^{-} / \mathrm{CD} 45 \mathrm{RO}^{+}$in four female cases (4 of 6). In contrast, all nine $\mathrm{r}-\mathrm{KIR}^{+} / \mathrm{r}_{-} \mathrm{TCR}^{-} \mathrm{SNLs}$ were male; the most common phenotype was $\mathrm{CD} 6^{+} / \mathrm{CD}_{4} 4^{-} / \mathrm{CD} 45 \mathrm{RO}^{+}$(5 of 9 ) and none had the $\mathrm{CD}^{-} 6^{-} / \mathrm{CD}_{4} 4^{-} / \mathrm{CD} 45 \mathrm{RO}^{+}$phenotype. For the 12 PTL cases, there was no sex predominance, the most common phenotype was $\mathrm{CD}^{-} 6^{-} / \mathrm{CD} 44^{+} /$ $\mathrm{CD}^{2} 5 \mathrm{RO}^{+}$(7 of 9), and two cases were $\mathrm{CD}^{-} 6^{-} /$ $\mathrm{CD}_{4}{ }^{-} / \mathrm{CD} 45 \mathrm{RO}^{+}$. Despite the expression of KIRs, the four female cases of $\mathrm{r}-\mathrm{KIR}^{+} / \mathrm{r}-\mathrm{TCR}^{+} \mathrm{SNL}$ were phenotypically unlike $r-\mathrm{KIR}^{+} / \mathrm{r}-\mathrm{TCR}^{-} \mathrm{SNLs}$, but similar to a minor subset of PTLs. The remaining two male cases of $\mathrm{r}-\mathrm{KIR}^{+} / \mathrm{r}-\mathrm{TCR}^{+} \mathrm{SNL}$ were $\mathrm{CD}^{+} 6^{+}$/ $\mathrm{CD} 5 \mathrm{RA}^{+}$, a phenotype not found in $\mathrm{r}-\mathrm{KIR}^{+} / \mathrm{r}-\mathrm{TCR}^{-}$ SNLs or PTLs. As shown below, the two genderassociated phenotypes in $\mathrm{r}-\mathrm{KIR}^{+} / \mathrm{r}-\mathrm{TCR}^{+}$SNLs implied very different clinical outcomes. 


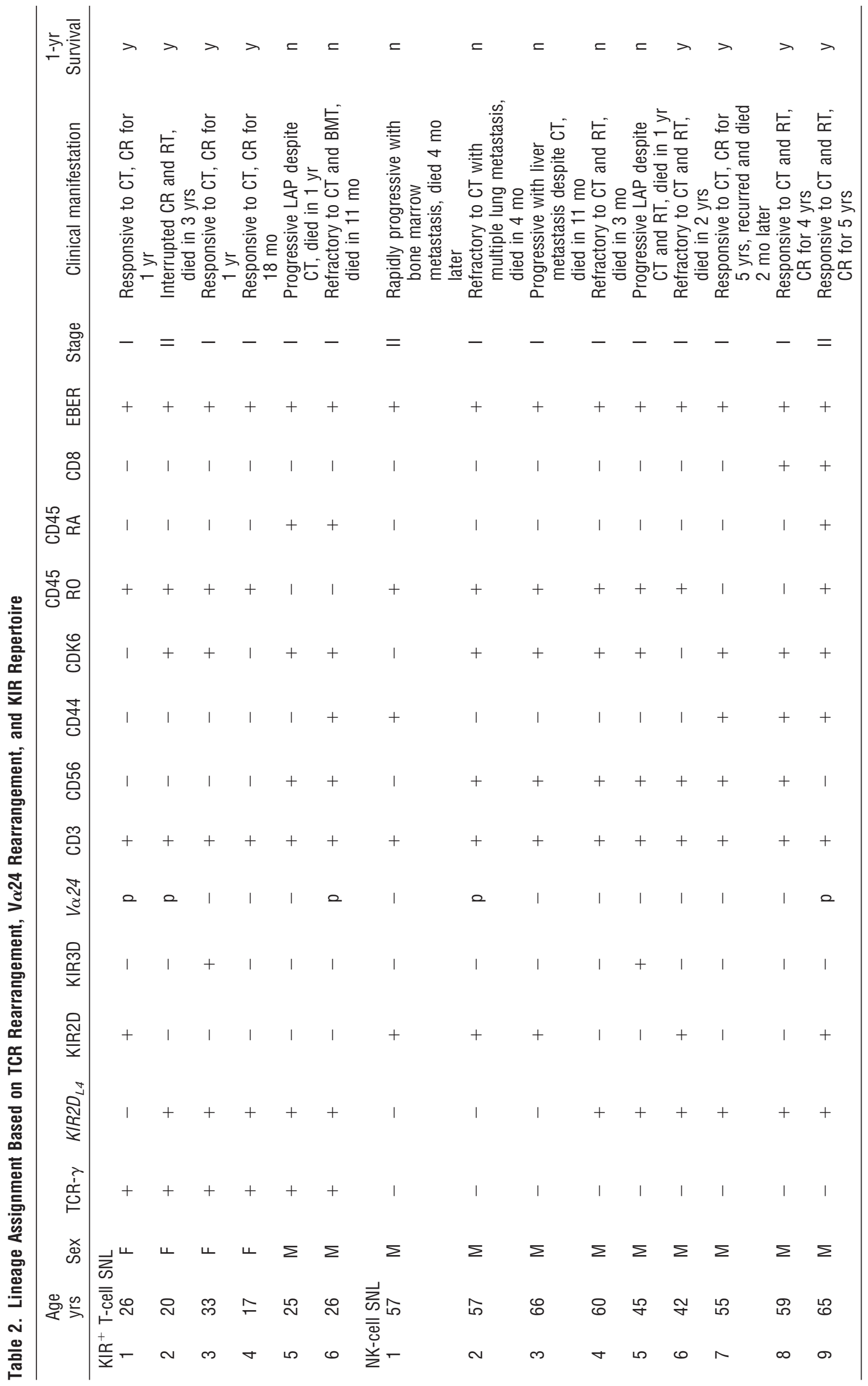


KIR Repertoire and TCR- $\gamma$ Rearrangement

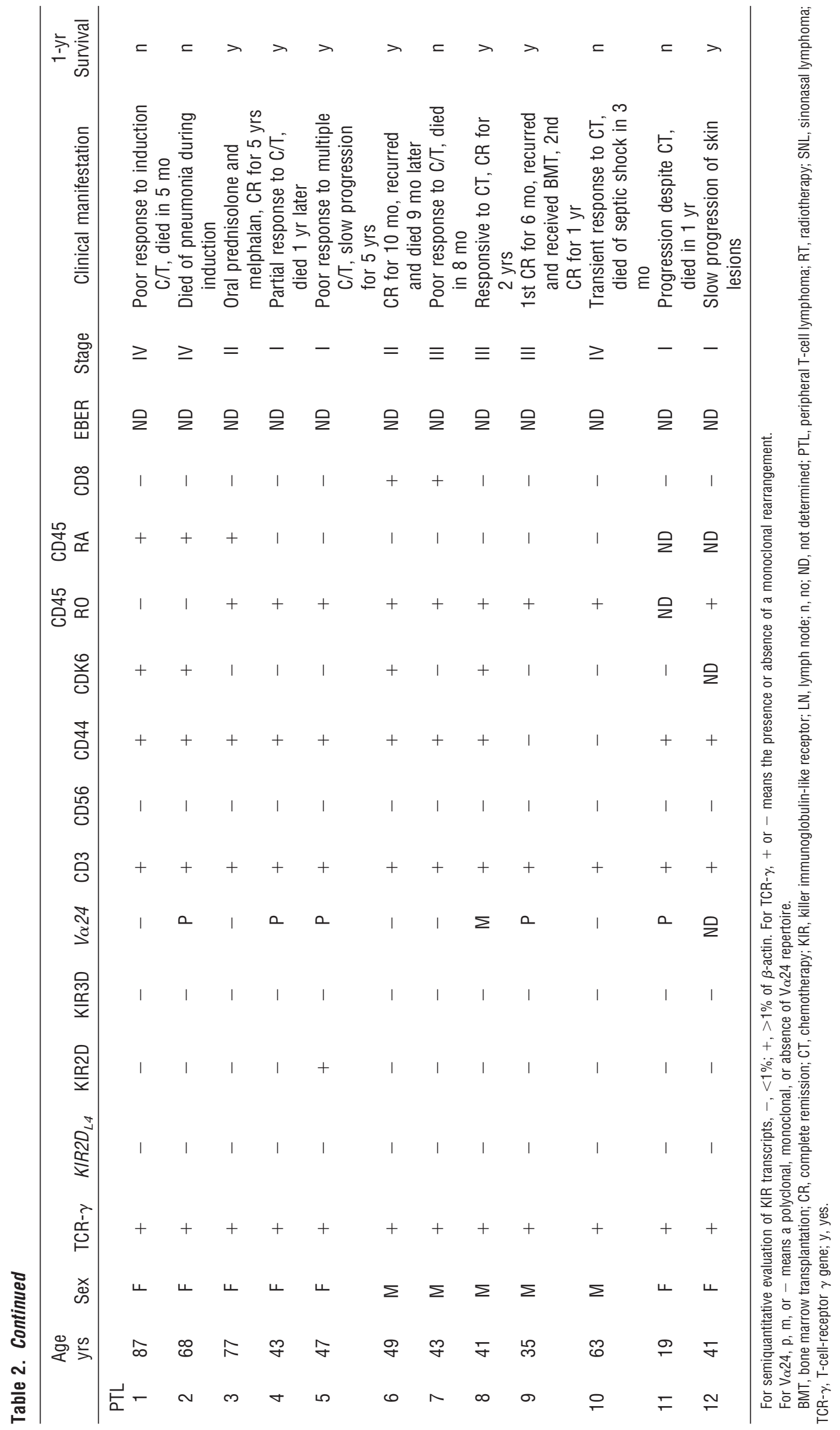


A

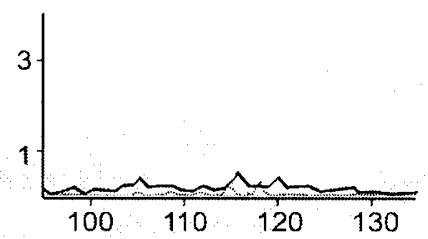

B

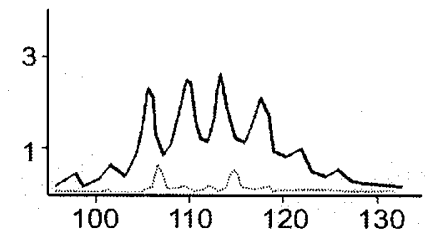

C

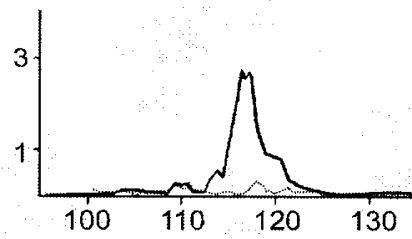

Figure 3.

Analysis of the $\mathrm{V} \alpha 24$ repertoire by RT-PCR. The solid tracings show a KIR + T-cell lymphoma with no $\mathrm{V} \alpha 24$ repertoire $(\mathrm{A})$, a KIR ${ }^{+} \mathrm{T}$-cell lymphoma with a polyclonal $\mathrm{V} \alpha 24$ repertoire (B), and a T-cell lymphoma with a monoclonal $\mathrm{V} \alpha 24$ repertoire $(\mathrm{C})$. The dashed tracings are the corresponding negative control cases run under the same conditions except for the omission of reverse transcriptase.

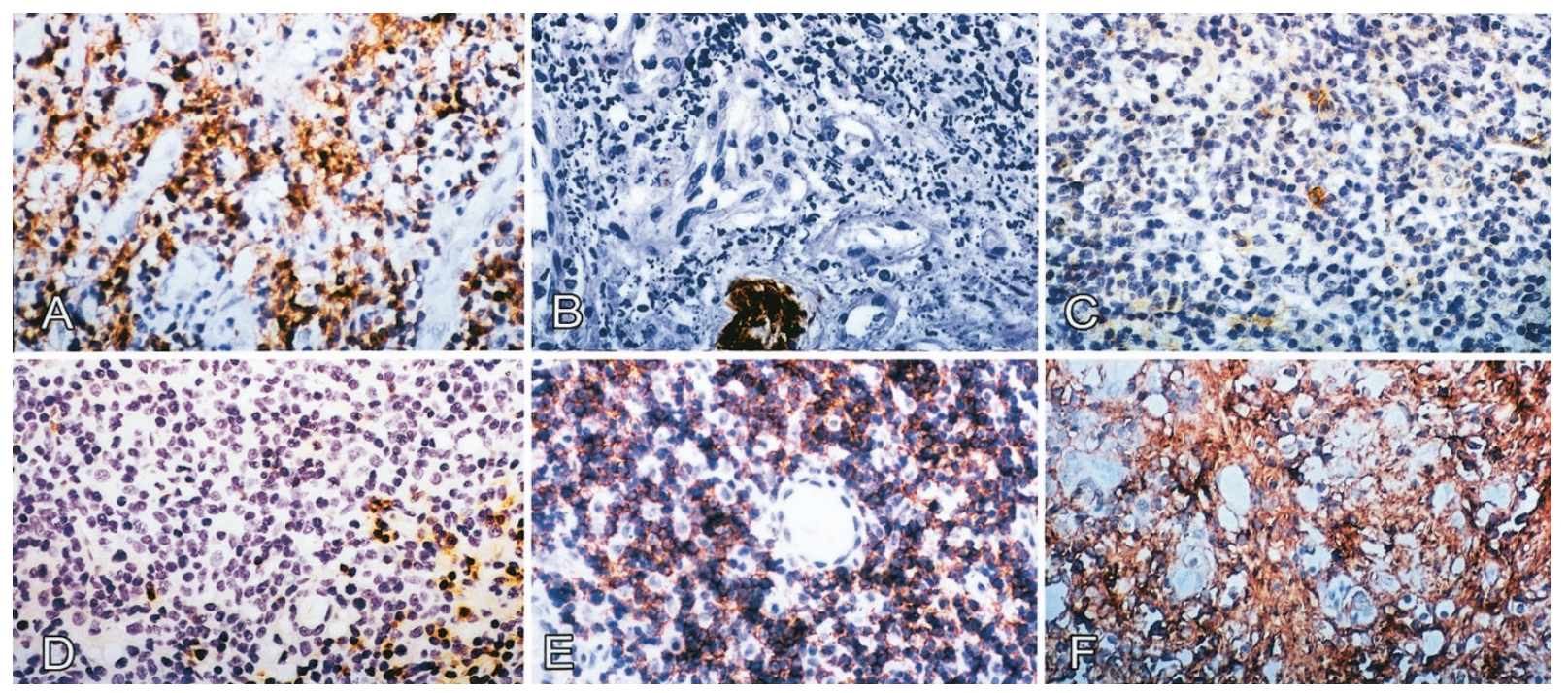

Figure 4.

A female case of $\mathrm{KIR}^{+} \mathrm{T}$-cell sinonasal lymphoma (SNL) with the $\mathrm{CD} 45 \mathrm{RO}^{+}, \mathrm{CD} 56^{-}$, and $\mathrm{CD} 44^{-}$phenotype is shown in $\mathrm{A}, \mathrm{B}$, and $\mathrm{C}$, respectively. A male case of $\mathrm{KIR}^{+} \mathrm{T}$-cell SNL with the $\mathrm{CD} 45 \mathrm{RO}^{-}, \mathrm{CD}_{5} 6^{+}$, and $\mathrm{CD} 44^{+}$phenotype is shown in $\mathrm{D}, \mathrm{E}$, and $\mathrm{F}$, respectively.

\section{Clinicopathologic Correlation}

Most SNLs had mixed small and large cells, and $\mathrm{r}-\mathrm{KIR}^{+} / \mathrm{r}-\mathrm{TCR}^{+} \mathrm{SNLs}$ did not differ morphologically from $\mathrm{r}-\mathrm{KIR}^{+} / \mathrm{r}-\mathrm{TCR}^{-} \mathrm{SNLs}$. The median age at diagnosis for the six $\mathrm{r}-\mathrm{KIR}^{+} / \mathrm{r}-\mathrm{TCR}^{+} \mathrm{SNLs}$ was lower than that for $\mathrm{r}-\mathrm{KIR}^{+} / \mathrm{r}-\mathrm{TCR}^{-}$SNLs (26 years versus 57 years). Also, only two of the six $\mathrm{r}-\mathrm{KIR}^{+} / \mathrm{r}-\mathrm{TCR}^{+} \mathrm{SNL}$ cases were male, but all nine $\mathrm{r}-\mathrm{KIR}^{+} / \mathrm{r}-\mathrm{TCR}^{-} \mathrm{SNL}$ cases were male.

Only two of the six $\mathrm{r}-\mathrm{KIR}^{+} / \mathrm{r}-\mathrm{TCR}^{+} \mathrm{SNL}$ cases died within 1 year, whereas five of the nine $\mathrm{r}-\mathrm{KIR}^{+} / \mathrm{r}-\mathrm{TCR}^{-}$ SNL cases died within 1 year. It is of interest to note that, within $\mathrm{r}-\mathrm{KIR}^{+} / \mathrm{r}-\mathrm{TCR}^{+} \mathrm{SNLs}$, all four female cases were $\mathrm{CD}^{-} 6^{-}$and survived for at least 1 year, but the two male cases were $\mathrm{CD}_{56}{ }^{+}$and died within 1 year. When the four female cases were compared with the 11 male cases of SNL $\left(2 \mathrm{r}-\mathrm{KIR}^{+} / \mathrm{r}-\mathrm{TCR}^{+} \mathrm{SNLs}\right.$ and 9 $\left.\mathrm{r}-\mathrm{KIR}^{+} / \mathrm{r}-\mathrm{TCR}^{-} \mathrm{SNLs}\right)$, the four female cases had an excellent 1 -year survival rate (4 of 4 versus 4 of $11, p$ $=0.05$ ).

Taken together, despite similar histopathology, the four female cases of $\mathrm{r}-\mathrm{KIR}^{+} / \mathrm{r}-\mathrm{TCR}^{+} \mathrm{SNL}$ appear to constitute a distinct subgroup of SNLs, characterized by a young age of onset, a CD $56^{-} / \mathrm{CD} 44^{-} / \mathrm{CD} 45 \mathrm{RO}^{+}$ phenotype, and an excellent prognosis. The two male patients expressed CD56 and, despite the presence of TCR $\gamma$ rearrangement, had a worse prognosis similar to the true NK cell lymphomas.

\section{Discussion}

Because most lymphomas are neoplastic counterparts of lymphocytes, a classification of lymphomas should first assign the lineage, then specify the developmental stages or functional subsets within the lineage. In the current WHO classification, B-cell lymphomas are put in a distinct group that includes entities such as follicular lymphoma, mantle cell lymphoma, and marginal-zone lymphoma, corresponding to subsets of B-cell development. In contrast, T-cell and NK-cell lymphomas are placed in a group and classified according to a variety of criteria, including histologic and clinical features, sites of involvement, and etiologic agents. Although a functional model using T-cell subset-specific genes from the tumor necrosis factor receptor family was proposed (Jones and Dorfman, 2001), this model does not apply to the general problem of distinguishing a T-cell lymphoma from an NK-cell lymphoma, and to the question whether a lymphoma of mixed NK/T lineage exists. 
Recently, we used the status of TCR rearrangement and KIR repertoire to separate the $T$ lineage from the NK lineage (Lin et al, 2001). In our scheme, a monoclonal $r-\mathrm{TCR}^{+}$represents a T lineage. A restricted KIR repertoire without a monoclonal TCR rearrangement $\left(r-\mathrm{KIR}^{+} / \mathrm{r}-\mathrm{TCR}^{-}\right)$represents an NK lineage (Table 1$)$. We successfully showed that a subset of SNLs belongs to the true NK lineage. In the present study, we further demonstrate that the same approach can also be used for isolating a subset of T-cell lymphomas with $\mathrm{NK}$-cell features, the $\mathrm{KIR}^{+} \mathrm{T}$-cell lymphomas $\left(r-\mathrm{KIR}^{+} / \mathrm{r}-\mathrm{TCR}^{+}\right)$. This is the most definitive evidence of a lymphoma of true mixed $\mathrm{NK} / \mathrm{T}$ lineage, and it echoes the WHO classification, in which NK and T lymphomas are put in a mixed group.

We have characterized the KIR repertoire by RTPCR, based on the three groups of alternative splicing. Depending on the length of cytoplasmic domain, long (L) or short (S), these three groups could be further classified into 12 subgroups, which were recently given CD designations, CD158a to CD158k plus CD158z (Andre et al, 2001). Based on immunohistochemistry, four groups reported $\mathrm{KIR}^{+} \mathrm{T}$-cell lymphomas. In the first report (Bagot et al, 2001), two cell lines from cutaneous $\mathrm{CD}^{+}{ }^{+} \mathrm{T}$-cell lymphoma cells were found to express KIR3DL2 (CD158k), but not KIR2DL1 (CD158a), KIR2DL2/L3 (CD158b), or KIR3DL1/S1 (CD158e). In the second report (Haedicke et al, 2000), one hepatosplenic $\gamma \delta$ T-cell lymphoma was positive for CD158a, but not for CD158b, CD158e, CD158k, or KIR2DS4 (CD158i). In the third report (Dukers et al, 2001), one intestinal T-cell lymphoma was positive for CD158a, but not for CD158b. In an additional study on lymphoid leukemia (Hoffmann et al, 2000), two T-cell large granular lymphocyte leukemias and one chronic lymphoproliferative disorder of $\gamma \delta \mathrm{T}$ cells expressed CD158e and CD158k, but not CD158i. Although the total published case number is small, these reports do recognize that a subgroup of T-cell lymphomas (ie, some T-cell lymphomas of cutaneous, intestinal, and hepatosplenic origins) could express some KIRs but not all KIRs. These lymphomas thus have a restricted KIR repertoire. In our study, we used the RT-PCR approach, which is more sensitive than immunohistochemistry, and showed, in a systematic survey, that a significant number of SNLs were $\mathrm{r}-\mathrm{KIR}^{+}$.

The identification of $r-\mathrm{KIR}^{+} / r-\mathrm{TCR}^{+} \mathrm{SNLs}$ raises the question of their normal counterparts. Various subsets of mature $\mathrm{T}$ cells may express KIRs. These include $\mathrm{CD}^{+}{ }^{+}$helper T cells, CD8 ${ }^{+}$cytotoxic T cells, $\gamma \delta \mathrm{T}$ cells, and intraepithelial $\mathrm{T}$ cells (Bertrand and Karlsson, 2000; McMahon and Raulet, 2001; Mingari et al, 1996; Ugolini et al, 2001). In addition, a unique T-cell subset with NK features, known as NKT cells, may express KIRs (Godfrey et al, 2000; Norris et al, 1999). NKT cells are $\mathrm{V} \alpha 24^{+}$and can be distinguished from $\mathrm{KIR}^{+} \mathrm{T}$ cells. Our study shows that none of the $\mathrm{KIR}^{+} \mathrm{T}$-cell lymphomas had a monoclonal $\mathrm{V} \alpha 24$ repertoire, indicating that $\mathrm{KIR}^{+} \mathrm{T}$-cell lymphomas are distinct from NKT-cell lymphomas. Furthermore, NKT cells use a special TCR with an invariant $\mathrm{V} \alpha 24$ chain to recognize glycolipid antigens presented by CD1d molecules. In con- trast, $\mathrm{KIR}^{+} \mathrm{T}$ cells are known to be present in viral infections; they are frequently cytotoxic memory $T$ cells. It is interesting to note that most SNLs, regardless of their phenotypes and genotypes, have a strong association with EBV infection.

Although T cells express KIRs, the function of KIRs of $T$ cells might be modulatory rather than inhibitory as in NK cells. It would be of interest to see whether the KIRs are differentially distributed on the NK lineage versus the $\mathrm{KIR}^{+} \mathrm{T}$ lineage. In our series, KIR2DL4 (CD158d) is the predominant one; we could not find any different patterns of KIR repertoires between $\mathrm{KIR}^{+}$ T-cell SNLs and NK-cell SNLs. This may be caused by the simplified approach that divides the KIRs roughly into three groups based on alternative splicing. A more extensive study to characterize the individual KIRs might be required to detect the difference between $\mathrm{KIR}^{+} \mathrm{T}$-cell SNLs and NK-cell SNLs.

Even with the limited cases available for study, we have shown a correlation between the lineage assignment and clinical manifestation (prognosis), patients with $\mathrm{KIR}^{+} \mathrm{T}$-cell SNLs are younger, more likely to be female and to be $\mathrm{CD}^{-}{ }^{-}$, and had a better prognosis. In the largest report on nasal and nasopharyngeal lymphomas (Cheung et al, 1998), the lymphomas were divided into the $\mathrm{CD}^{+} 6^{+}$and $\mathrm{CD}^{-} 6^{-}$categories. It was found that the $\mathrm{CD}^{2} 6^{+}$category had a worse prognosis than did the $\mathrm{CD}^{-} 6^{-}$category. Our results confirm and extend this previous report.

In conclusion, our study indicates that most T-celltype SNLs are related to $\mathrm{KIR}^{+} \mathrm{T}$-cells, but do not come from NKT cells. We do not suggest that $\mathrm{KIR}^{+}$ T-cell SNLs are derived from the bi-potential T/NK precursor. The bipotent T/NK precursor is positive for the terminal deoxynucleotidyl transferase, but has not rearranged the T-cell receptor, nor expressed KIRs (Carlyle and Zuniga-Pflucker, 1998). The identification of a mixed NK/T-cell lymphoma echoes the WHO classification, in which the T-cell and NK-cell lymphomas are placed in a single category.

\section{Materials and Methods}

\section{Tissue Samples}

Tissue sections and medical records of all SNL cases (total 15) at the Department of Pathology, National Taiwan University Hospital, in the period from 1996 to 1999, were reviewed by two independent hematopathologists. The diagnosis was made initially by a combination of morphology, immunohistochemistry, and clinical features according to the WHO classification. ${ }^{1}$ In addition, 12 cases of PTL in the lymph nodes were used as T-lineage control cases. All 12 cases had a monoclonal TCR- $\gamma$ rearrangement.

\section{Nucleic Acid Extraction}

Genomic DNA was extracted from formalin fixed paraffin-embedded tissue blocks using a QIAamp kit (QIAGEN, Valencia, California). RNA was also extracted from formalin-fixed, paraffin-embedded tissue blocks by the Trizol method. One-tenth microgram of 
extracted DNA was used for each PCR, and $0.1 \mu \mathrm{g}$ of purified RNA was used for each RT-PCR.

\section{Standard Conditions for RT, PCR, and High-Resolution Electrophoresis}

Reverse transcription was performed in a $20 \mu \mathrm{l}$ mixture composed of $0.1 \mu \mathrm{g}$ of purified RNA, $0.5 \mu \mathrm{m}$ antisense primer, 200 units reverse transcriptase, 50 $\mathrm{mm}$ Tris- $\mathrm{HCl}$ at $\mathrm{pH} 8.3,75 \mathrm{~mm} \mathrm{KCl}, 3 \mathrm{~mm} \mathrm{MgCl}_{2}, 10 \mathrm{~mm}$ DTT, and $200 \mu \mathrm{M}$ of each dNTP. The reaction was performed at $42^{\circ} \mathrm{C}$ for 50 minutes.

All of the PCR reactions in this report were run in a $20 \mu \mathrm{l}$ reaction mixture. Each $20 \mu \mathrm{l}$ reaction mixture contained $0.1 \mu \mathrm{g}$ of extracted DNA, $0.3 \mu \mathrm{M}$ of each primer set, $15 \mathrm{~mm}$ Tris- $\mathrm{HCl}(\mathrm{pH} 8.0), 1.5 \mathrm{~mm} \mathrm{MgCl}_{2}, 50$ $\mathrm{mm} \mathrm{KCl}, 200 \mu \mathrm{M}$ of each dNTP, and 1 unit of Taq polymerase. The reaction mixture was subjected to 35 cycles of PCR. Each cycle consisted of denaturation at $94^{\circ} \mathrm{C}$ for 45 seconds, annealing at $45^{\circ} \mathrm{C}$ for 45 seconds, and extension at $72^{\circ} \mathrm{C}$ for 45 seconds. For electrophoresis, a portion of the PCR product was loaded on and separated by a high-resolution DNA analyzer ( $\mathrm{ABI} 377$ equipped with GeneScan software, Perkin-Elmer, Foster City, California).

\section{Group Specific RT-PCR for KIR}

Characterization of KIR repertoires by RT-PCR is a well-established approach (Uhrberg et al, 1997; Valiante et al, 1997). A simplified group-specific RT-PCR was also developed that demonstrated a restricted KIR repertoire as a clonality test for NK cells (Lin et al, 2001).

Briefly, KIR receptors share a consensus sequence composed of a leader sequence followed by three immunoglobulin (lg)-like domains, and can be categorized into three groups according to the unique domain junctions created by alternative splicing (Steffens et al, 1998; Wilson et al, 1997). Three pairs of group-specific primers were designed to target the unique junctions: $5^{\prime}-$ GCTGAGAGAGAAGGTTCTCATAT-3' (723-700) and 5'CACTCCCCCACTGGGTGG TCGGC-3' (341-363) for the $1^{\text {st }}-3^{\text {rd }}$ domain junction of group $2 D_{L 4}, 5^{\prime}-$ TGGGTGGGCCAGAGGAAGGTTT-3' (430-406) and 5'CATGGCGTGTGTTGGGTTCTTCTTG-3' (61-85) for the leader sequence- $2^{\text {nd }}$ domain junction of group $2 \mathrm{D}$, and 5'-TGGGTGGGCCAGGAGGAAGGTTT-3' (430-406) and 5'-CACTCCCCCCACTGGGTGGTCGGC-3' (341$363)$ for the $1^{\text {st }}-2^{\text {nd }}$ domain junction of group $3 D$.

For each lymphoma, three group specific reversetranscription reactions for the KIRs and one for $\beta$-actin as the positive control were performed with $0.1 \mu \mathrm{g}$ of extracted RNA as the starting material. As negative control cases, four corresponding reactions without reverse transcriptase were run simultaneously. One tenth of the reaction mixture was used as the template for PCR under the standard condition, with $2 \mu \mathrm{M}$ [TAMRA]-dCTP added as the fluorescence label. A typical result analyzed by GeneScan is shown in Figure 1. An NK-cell lymphoma should have a restricted KIR repertoire (C), in contrast to a reactive condition that should have an unrestricted KIR repertoire $(A)$ or no KIR repertoire $(B)$.

\section{T-Cell-Receptor $\gamma$ Gene Rearrangement}

The variable regions of TCR- $\gamma$ can be put into 4 groups. Consequently, the status of TCR- $\gamma$ rearrangement was examined by 4 separate nested PCRs, corresponding to the 4 variable regions, $\mathrm{V}_{\gamma} \mathrm{I}, \mathrm{V} \gamma \mathrm{ll}$, $\mathrm{V} \gamma \mathrm{III}$, and $\mathrm{V} \gamma \mathrm{IV}$. This approach has a sensitivity of $90 \%$ and a specificity of $70 \%$, comparable with a similar PCR-based test (Lin et al, 2002; Vega et al, 2001).

The primers were $V_{1}$ 5'-TCAGGAATCAGTCCAGGAAAGTAT-3'; $V_{\| 1}$ 5'-GAAAGGAATCTGGCATTCCG-3'; V $V_{\text {III }}$ 5'-AAGCAACAAAGTGGAGGCAAGAAAG-3'; VIV 5'-CTCACACTC(TC)CACTTC-3'; J $\gamma 1 / 2$ 5'-CAAGTGTTGTTCCACTGCC-3'; J yp 5'-TTGTTCCGGGACCAAATACC-3'; J yp1/2 5'-GTTACTATGAGC(CT)TAGTC-3'; V ' 5'-6-FAM*-TCTGG(AG)GTCTATTACTGTGC-3'; $V_{11}^{\prime} \quad 5^{\prime}-6-$ FAM $^{*}-$ ATAGCTAC

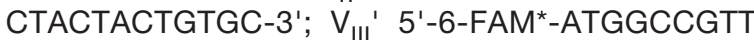
TACTACTGTGC-3'; $V_{\text {IV }}{ }^{\prime}$ 5'-6-FAM*-GAGGTGGTG TACCACTGTGC-3'; J $\gamma 1 / 2$ ' 5'-AGTGTTGTTCCACT GCCAAAGAGTTT-3'; J $\gamma \mathrm{p}^{\prime}$ 5'-AGCTTTGTTCCG GGACCAAATACCTT-3'; J Jp1' 5'-AGCTTAGTCC CTTCAGCAAATATCT T-3'; J $\gamma p 2$ ' 5'-AGCCTAGTCC CTTTTGCAAACGTCTT-3'.

For example, to assay $\mathrm{V} \gamma \mathrm{l}-\mathrm{J}$ recombination, we used a $V \gamma$ l-specific primer $\left(V_{1}\right)$ and a mixture of $\mathrm{J}$-primers $(\mathrm{J} \gamma 1 / 2, \mathrm{~J} \gamma \mathrm{p}$, and $\mathrm{J} \gamma \mathrm{p} 1 / 2)$ to amplify $0.1 \mu \mathrm{g}$ of extracted DNA in the initial PCR. This was followed by a nested PCR, with use of a second fluorescencelabeled $\mathrm{V} \gamma \mathrm{l}$-specific primer $\left(\mathrm{V}_{1}{ }^{\prime}\right)$, a second mixture of J-primers (J $\gamma 1 / 2{ }^{\prime}, J \gamma p^{\prime}, J \gamma p 1^{\prime}$, and J J p2'), and $2 \mu$ of the initial PCR mixture as the DNA template. The same procedures were repeated for $V \gamma\|l-J, V \gamma\| I I-J$, and $\mathrm{V} \gamma \mathrm{IV}-\mathrm{J}$ rearrangements. A typical result is shown in Figure 2.

\section{RT-PCR for Vo24 Repertoire}

The TCR- $\alpha$ chain is composed of a variable segment $(\mathrm{V} \alpha)$, a $\mathrm{J}$ segment $(\mathrm{J} \alpha)$, and a constant domain $(\mathrm{C} \alpha)$. For most T cells, the $\mathrm{V} \alpha \mathrm{J} \alpha$ rearrangement is random, but NKT cells are characterized by an invariant $\alpha$ chain, $\mathrm{V} \alpha 24 \mathrm{~J} \alpha \mathrm{q}$ (Porcelli et al, 1993; Prussin and Foster, 1997). An NKT-cell lymphoma would have a monoclonal Va24 repertoire. We thus used an RT-PCR approach modified from previous reports to screen the $\mathrm{V} \alpha 24$ repertoire (Mempel et al, 2000; Porcelli et al, 1993), ie, all of the transcripts involving the recombination $\mathrm{V} \alpha 24-\mathrm{J} \alpha-\mathrm{C} \alpha$.

Specifically, RNA was reverse-transcribed by a reverse $\mathrm{C} \alpha$ primer (5'-TTTAGAGTCTCTCAGCTGGTACAC-3'), and the CDNA was PCR-amplified by addition of a forward $\mathrm{V} \alpha 24$ primer (5'-ATCACAGC CTCCCAGCTCAGC-3'). The resulting PCR products were re-amplified by a nested PCR by use of a $V \alpha 24$ primer (5'-GATTCAGCCTCCTACATCTGTGTG-3') and a fluorescence-labeled $\mathrm{C} \alpha$ primer (5'-HE-GGCAGGGTCAGGGTTCTGGAT-3'). The conditions for the RT, PCR, and nested PCR were identical to those for 
KIRs, and a negative control without reverse transcriptase was also included. At the end of the nested PCR, the products were loaded and analyzed by GeneScan. A typical result is shown in Figure 3.

\section{Immunohistochemistry}

Immunohistochemistry was performed on formalinfixed, paraffin-embedded tissue sections. All antibodies were commercially available and were used according to the manufacturer's recommendation. These antibodies include CD3, CD8, CD45RA, and CD45RO (Dako SA, Glostrup, Denmark), CD56 (Novocastra Lab LTD, Newcastle, United Kingdom), CDK6 (Santa Cruz Biotechnology, Santa Cruz, California), and CD44 (R\&D Systems LTD, Minneapolis, Minnesota).

\section{References}

Andre P, Biassoni R, Colonna M, Cosman D, Lanier LL, Long EO, Lopez-Botet M, Moretta A, Moretta L, Parham P, Trowsdale J, Vivier E, Wagtmann N, and Wilson MJ (2001). New nomenclature for MHC receptors. Nat Immunol 2:661.

Bagot M, Moretta A, Sivori S, Biassoni R, Cantoni C, Bottino C, Boumsell L, and Bensussan A (2001). CD4+ cutaneous T-cell lymphoma cells express the p140-killer cell immunoglobulin-like receptor. Blood 97:1388-1391.

Bertrand $\mathrm{H}$ and Karlsson $\mathrm{L}$ (2000). KIR expression on selfreactive $\mathrm{CD}^{+} \mathrm{T}$ cells is controlled by $\mathrm{T}$-cell receptor engagement. Nature 403:321-328.

Carlyle JR and Zuniga-Pflucker JC (1998). Lineage commitment and differentiation of $T$ and natural killer lymphocytes in the fetal mouse. Immunol Rev 165:63-74.

Cheung MM, Chan JK, Lau WH, Foo W, Chan PT, Ng CS, and Ngan KC (1998). Primary non-Hodgkin's lymphoma of the nose and nasopharynx: Clinical features, tumor immunophenotype, and treatment outcome in 113 patients. $\mathrm{J}$ Clin Oncol 16:70-77.

Chiang AK, Chan AC, Srivastava G, and Ho FC (1997). Nasal T/natural killer (NK)-cell lymphomas are derived from Epstein-Barr virus-infected cytotoxic lymphocytes of both NK- and T-cell lineage. Int J Cancer 73:332-338.

Dukers DF, Vermeer MH, Jaspars LH, Sander CA, Flaig MJ, Vos W, and Willemze R (2001). Expression of killer cell inhibitory receptors is restricted to true NK cell lymphomas and a subset of intestinal enteropathy-type T cell lymphomas with a cytotoxic phenotype. J Clin Pathol 54:224-228.

Godfrey DI, Hammond JL, Poulton LD, Smyth MJ, and Baxter AG (2000). NKT cells: Fact, functions and fallacies. Immunol Today 21:573-583.

Haedicke W, Ho FC, Chott A, Moretta L, Rudiger T, Ott G, and Muller-Hermelink HK (2000). Expression of CD94/ NKG2A and killer immunoglobulin-like receptors in NK cells and a subset of extranodal cytotoxic T-cell lymphomas. Blood 95:3628-3630.

Hoffmann T, De Libero G, Colonna M, Wodnar-Filipowicz A, Passweg J, Favre G, Gratwohl A, and Tichwlli A (2000). Natural killer-type receptors for HLA class I antigens are clonally expressed in lymphoproliferative disorders of natural killer cell and T-cell type. Br J Haematol 110:525-536.
Jaffe ES, Harris NL, Stein H, and Vardiman JW (2001). World Health Organization classification of tumors. Pathology and genetics of tumors of haematopoietic and lymphoid tissues. IARC Press, Lyon, France.

Jones D and Dorfman DM (2001). Phenotypic characterization of subsets of $T$ cell lymphoma: Towards a functional classification of T cell lymphoma. Leuk Lymphoma 40:449459.

Kanavaros P, Lescs MC, Briere J, Divine M, Galateau F, Joab I, Bosq J, Farcet JP, Reyes F, and Gaulard P (1993). Nasal T-cell lymphoma: A clinicopathologic entity associated with peculiar phenotype and with Epstein-Barr virus. Blood 81: 2688-2695.

Lien HC, Lin CW, Huang PH, Chang ML, and Hsu SM (2000). Expression of cyclin-dependent kinase 6 and frequent loss of CD44 in nasal-nasopharyngeal NK/T cell lymphomas: Comparison with CD56-negative peripheral T-cell lymphomas. Lab Invest 80:893-900.

Lin CW, Chang CL, Li CC, Chen YH, Lee WH, and Hsu SM (2002). Spontaneous regression of Kikuchi lymphadenopathy with oligoclonal T-cell populations favors a benign immune reaction over a T-cell lymphoma. Am J Clin Pathol 117:627635.

Lin CW, Lee WH, Chang CL, Yang JY, and Hsu SM (2001). Restricted killer cell immunoglobulin-like receptor repertoire without T-cell receptor $\gamma$ rearrangement supports a true NK-cell lineage in a subset of sinonasal lymphomas. Am J Pathol 159:1671-1679.

Long EO and Rajagopalan S (2000). HLA class I recognition by killer cell Ig-like receptors. Semin Immunol 12:101-108.

McMahon CW and Raulet D (2001). Expression and function of NK cell receptors in CD8 $+\mathrm{T}$ cells. Curr Opin Immunol 13:465-470.

Mempel M, Flageul B, Suarez F, Ronet C, Dubertret L, Kourilsky P, Gachelin G, and Musette P (2000). Comparison of the $T$ cells patterns in leprous and cutaneous sarcoid granulomas: Presence of $\mathrm{V} \alpha 24$-invariant natural killer $\mathrm{T}$ cells in T-cell-reactive leprosy together with a highly biased $\mathrm{T}$ cell receptor $\mathrm{V} \alpha$ repertoire. Am J Pathol 157:509-523.

Mingari MC, Schiavetti F, Ponte M, Vitale C, Maggi E, Romagnani S, Demarest J, Pantaleo G, Fauci AS, and Moretta L (1996). Human CD8+ T lymphocyte subsets that express HLA class I-specific inhibitory receptors represent oligoclonally or monoclonally expanded cell populations. Proc Natl Acad Sci USA 93:12433-12438.

Moretta A, Bottino C, Vitale M, Pende D, Biassoni R, Mingari MC, and Moretta L (1996). Receptors for HLA class I molecules in human natural killer cells. Annu Rev Immunol 14: 619-648.

Nagata H, Konno A, Kimura N, Zhang Y, Kimura M, Demachi A, Sekine T, Yamamoto K, and Shimizu N (2001). Characterization of novel natural killer (NK)-cell and $\gamma \Delta$ T-cell lines established from primary lesions of nasal T/NK-cell lymphomas associated with the Epstein-Barr virus. Blood 97:708713.

Norris S, Doherty DG, Collins C, McEntee G, Traynor O, Hegarty JE, and O'Farrelly C (1999). Natural T cells in the human liver: Cytotoxic lymphocytes with dual $\mathrm{T}$ cell and natural killer cell phenotype and function are phenotypically heterogeneous and include $\mathrm{V} \alpha 24-\mathrm{J} \alpha \mathrm{Q}$ and $\gamma \Delta \mathrm{T}$ cell receptor bearing cells. Hum Immunol 60:20-31. 
Porcelli S, Yockey CE, Brenner MB, and Balk SP (1993). Analysis of $T$ cell antigen receptor (TCR) expression by human peripheral blood $\mathrm{CD}^{-} 8^{-} \alpha / \beta$ T cells demonstrates preferential use of several $\mathrm{V} \beta$ genes and an invariant TCR $\alpha$ chain. J Exp Med 178:1-16.

Prussin C and Foster B (1997). TCR Va24 and Vb11 coexpression defines a human NK1 T cell analog containing a unique Th0 subpopulation. J Immunol 159:5862-5870.

Raulet DH, Vance RE, and McMahon CW (2001). Regulation of the natural killer cell receptor repertoire. Annu Rev Immunol 19:291-330.

Steffens U, Vyas Y, Dupont B, and Selvakumar A (1998). Nucleotide and amino acid sequence alignment for human killer cell inhibitory receptors (KIR), 1998. Tissue Antigens 51:386-413.

Suzumiya J, Takeshita M, Kimura N, Kikuchi M, Uchida T, Hisano S, Eura Y, Kozuru M, Nomura Y, and Tomita K (1994). Expression of adult and fetal natural killer cell markers in sinonasal lymphomas. Blood 83:2255-2260.

Ugolini S, Arpin C, Anfossi N, Walzer T, Cambiaggi A, Forster R, Lipp M, Toes RE, Melief CJ, Marvel J, and Vivier E (2001). Involvement of inhibitory NKRs in the survival of a subset of memory-phenotype CD8+ T cells. Nat Immunol 2:430-435.

Uhrberg M, Valiante NM, Shum BP, Shilling HG, LienertWeidenbach K, Corliss B, Tyan D, Lanier LL, and Parham P (1997). Human diversity in killer cell inhibitory receptor genes. Immunity 7:753-763.

Valiante NM, Uhrberg M, Shilling HG, Lienert-Weidenbach K, Arnett KL, D'Andrea A, Phillips JH, Lanier LL, and Parham P (1997). Functionally and structurally distinct NK cell receptor repertoires in the peripheral blood of two human donors. Immunity 7:739-751.

Vega F, Medeiros LJ, Jones D, Abruzzo LV, Lai R, Manning J, Dunmire V, and Luthra R (2001). A novel four-color PCR assay to assess $\mathrm{T}$-cell receptor gamma gene rearrangement in lymphoproliferative lesions. Am J Clin Pathol 116:17-24.

Wilson MJ, Torkar M, and Trowsdale J (1997). Genomic organization of a human killer cell inhibitory receptor gene. Tissue Antigens 49:574-579.

Warren HS and Skipsey LJ (1991). Loss of activation-induced CD45RO with maintenance of CD45RA expression during prolonged culture of $\mathrm{T}$ cells and NK cells. Immunology $74: 78-85$. 